\title{
Sistem Kepercayaan dan Peran Perempuan Terhadap Pengelolaan Sumberdaya Hutan di Luwu Timur
}

\author{
${ }^{1}$ Jumardi Lanta, ${ }^{2}$ Pawennari Hijjang, ${ }^{3}$ Safriadi \\ ${ }^{1}$ COMMIT Foundation, Indonesia \\ 2,3 Department Antropologi, FISIP Universitas Hasanuddin
}

Email Coresponden:mardi_mks@yahoo.com

\begin{tabular}{l}
\hline ARTICLE INFO \\
\hline Keywords: \\
Pengelolaan hutan; \\
Perempuan; sistem \\
kepercayaan; peran; \\
sumberdaya. \\
\\
How to cite: \\
Lanta, J., Hijjang, P., \\
Safriadi. (2019). Sistem \\
Kepercayaan dan Peran \\
Perempuan Terhadap \\
Pengelolaan Sumberdaya \\
Hutan di Desa Lanosi \\
Kabupaten Luwu Timur. \\
ETNOSIA: Jurnal \\
Etnografi Indonesia. 4(1): \\
41 - 58. \\
DoI: \\
10.31947/etnosia.v4i1.5941 \\
\hline
\end{tabular}

\begin{abstract}
This article aims to (1) describe the local community belief system in preserving the forest so that the forest, (2) analyze the factors that influence the local community to convert forest functions (3) Analyze the role of women in preserving forest resources. The research method is a qualitative method with in-depth interview and observation data collection techniques and use PRA (Participatory Rural Appraisal). The results of the study show that there is a well-preserved community belief system known as "metompa/metabe" that is able to prevent people from carrying out massive deforestation at the research site. Likewise the existence of efforts to empower women to manage, maintain and preserve forest resources is an important aspect for women to increase their household income while protecting the forest from damage and extinction.
\end{abstract}

\section{Pendahuluan}

Ancaman kerusakan hutan merupakan hal yang serius dihadapi oleh seluruh masyarakat Luwu Timur, termasuk Desa Lanosi ${ }^{1}$. Komoditas merica atau lada merupakan hal yang menggoda seluruh petani di Kabupaten Luwu Timur

\footnotetext{
${ }^{1}$ (Kabar.news.Com, 13/05/2017 dan Online24.com, 16/05/2017)
} 
untuk membuka lahan perkebunan baru, tidak tanggung-tanggung hutan lindung pun merupakan sasaran para petani tersebut untuk digarap. Sementara itu perempuan yang selama ini banyak berperan memelihara sumberdaya hutan tidak mendapat akses yang cukup untuk meningkatkan pendapatan rumah tangganya. Sementara hasil penelitian yang dilakukan Sulawesi Community Foundation (SCF) menunjukkan bahwa terdapat sekelompok perempuan yang digolongkan sebagai perempuan marginal mengalami kehidupan yang tergolong miskin, mereka adalah janda, atau yang tidak memiliki suami dan atau orang tua tunggal (SCF, 2015).

Saya mengawali dengan teori fungsional sebagai episentrum dari tulisan ini yang selama ini kita kenal melalui pemikiran Malinowski tentang etnografi yang berintegrasi secara fungsional, konsepnya mengenai fungsi sosial dari adat, tingkah laku manusia dan pranata-pranata sosial. Kemudian ia membedakan antara fungsi sosial dalam tiga tingkat abstraksi (Koentjaraningrat, 2014: 167-168) yaitu: (1) Fungsi sosial dari suatu adat, pranata sosial atau unsur kebudayaan pada tingkat abstraksi pertama mengenai pengaruh atau efeknya terhadap adat, tingkah laku manusia dan pranata sosial lainnya dalam masyarakat; (2) Fungsi sosial dari suatu adat, pranata sosial atau unsur kebudayaan pada tingkat abstraksi kedua mengenai pengaruh atau efeknya terhadap kebutuhan suatu adat atau pranata lain untuk mencapai maksudnya, seperti yang dikonsepsikan oleh warga masyarakat yang bersangkutan; dan (3) Fungsi sosial dari suatu adat atau pranata sosial pada tingkat abstraksi ketiga mengenai pengaruh atau efeknya terhadap kebutuhan mutlak untuk berlangsungnya secara terintegrasi dari suatu sistem sosial tertentu.

Pandangan lain Malinowski tentang azas dari aktifitas pengendalian sosial atau hukum, ia menganalisa sebagai berikut: (1) Terhadap Masyarakat modern, tata tertib dijaga oleh antara lain oleh sistem pengendalian sosial yang bersifat memaksa, yaitu hukum. Untuk melaksanakannya hukum harus disokong oleh sistem alat-alat kekuasaan (kepolisian, pengadilan dan sebagainya) yang diorganisasi oleh Negara; (2) Terhadap masyarakat primitif alat-alat kekuasaan serupa itu kadang-kadang tidak ada. Dengan demikian apakah dalam masyarakat primitif tidak ada hukum? Pertanyaannya bagaimana masyarakat bisa menjaga tata tertib dan kelancaran kehidupan sosialnya. Sarjana lain berpendapat bahwa dalam masyarakat primitif ada kecondongan naluri antara individunya untuk segera spontan taat kepada adat istiadat.

Terkait dengan hal tata tertib dalam masyarakat tersebut, Malinowski memberi pandangan tentang mitologi atau himpunan dongeng-dongeng suci dalam masyarakat Trobriand pada khususnya, dan masyarakat pada umumnya. Hasil observasi Malinowski dari berbagai macam dongeng dalam masyarakat 
Trobriand terdapat dongeng suci yang dianggap kategori khusus yang mereka sebut liliu. Dongeng-dongeng ini oleh orang Trobriand tidak dianggap sebagai dongeng-dongeng pralambang saja, tetapi merupakan dongeng-dongeng suci yang dianggap nyata yang tak terikat pada tempat dan waktu, serta dianggap sebagai pedoman untuk upacara-upacara suci, untuk kesusilaan, dan dianggap sebagai alasan untuk berbagai aktifitas masyarakat lain.

Hal tersebut menjadi dasar analisa terhadap tindakan perempuan, apakah perempuan juga meyakini dan mempercayai mitologi yang hidup dalam masyarakat di Desa Lanosi mempengaruhi proses pengambilan tindakan terhadap pengelolaan sumberdaya hutan sebagai basis kepercayaan masyarakat. Karena hal tersebut bersifat umum, bukan hanya di Trobriand tetapi di Desa Lanosi juga hidup mitologi termasuk mitologi yang terkait pengelolaan sumberdaya hutan.

Pandangan lain berasal dari aliran fungsionalisme structural atau sering disebut aliran fungsionalisme adalah mazhab arus utama (mainstream) dalam ilmu sosial yang dikembangkan oleh Robert Merton dan Talcott Parsons, teori ini tidak secara langsung menyinggung perempuan tetapi keyakinan mereka bahwa masyarakat adalah satu sistem terdiri atas agama, pendidikan, struktur politik sampai keluarga. Masing-masing bagian secara terus menerus mencari keseimbangan (equilibrium) dan harmoni, dapat menjelaskan posisi mereka tentang perempuan. Interelasi itu karena konsensus, pola yang non normatif jika hal tersebut terjadi, maka masing-masing bagian berusaha secepatnya menyesuaikan diri untuk mencapai keseimbangan (Faqih, 2008:84).

Berdasarkan perspektif teori tersebut, kita bisa memotret bagaimana perempuan mengambil peran dalam pengelolaan sumberdaya hutan sebagai bagian dari penciptaan keseimbangan dalam rumah tangga, khususnya dalam hal pemenuhan kebutuhan dasar. Namun di sisi lain, perempuan juga berperan menjaga keseimbangan dalam menjaga kehidupan sosial melalui pendekatan kelompok.

Berdasarkan basis teori fungsional tersebut, maka artikel ini membantu bagaimana menganalisa pilihan perempuan untuk melibatkan diri secara aktif untuk mengelola dan memanfaatkan sumberdaya hutan. Meskipun secara normatif program-program yang berasal dari luar menawarkan dan menjanjikan berbagai keuntungan seperti ekologi dan ekonomi terhadap pengelolan sumberdaya hutan tersebut, tetapi perempuan memiliki pilihan tersendiri khususnya terkait pemenuhan kebutuhan dasar sebagai fokus pilihan (Chandra, E., 2010, Febrianto, A., 2016, Laksono, P.M., dkk, 2000 dan Widodo, S., 2009). Baik terkait dengan pemenuhan kebutuhan rumah tangga maupun terhadap kebutuhan kolektif masyarakat. 
Artikel ini bertujuan untuk menguraikan sejauh mana masyarakat khususnya perempuan mengelola sumberdaya hutan sebelum dan setelah adanya program pemerintah, perguruan tinggi maupun dari NGO/LSM. Secara spesifik artikel ini menguraikan; (1) Menggali sumber pengetahuan (kognitif), keterampilan dan kepercayaan/keyakinan yang dimiliki oleh masyarakat serta nilai budaya (value), mitologi, norma (norm) dan hukum yang ada, (2) Peranperan perempuan dalam pengelolaan sumberdaya hutan yakni jenis sumberdaya hutan apa yang dikelola, mekanisme pengelolaan sumberdaya hutan, pihak-pihak lain yang terlibat dalam pengelolaan sumberdaya hutan dan produk yang dihasilkan dan digunakan oleh masyarakat, (3) Kebijakan program yang mendorong keterlibatan perempuan dalam pengelolaan sumberdaya hutan serta peran unsur-unsur kelembagaan yang terkait dengan implementasi kebijakan tersebut seperti NGO/LSM, pemerintah melalui Dinas Kehutanan, Camat, Kepala Desa, RT/RW.

\section{Metode Penelitian}

Penelitian ini menggunakan pendekatan kualitatif. Pengumpulan data sekunder (secondary data) dan data primer (primary data) dilakukan dengan; (1) observasi umum keadaan desa, yakni melakukan pengamatan umum tentang kondisi desa serta keterkaitannya dengan pengelolaan sumberdaya hutan di Desa Lanosi membantu memvisualisasi hasil pengamatan tersebut dibantu dengan menggunakan tools PRA (Participatory Rural Appraisal) yakni sketsa desa (Gambar 1) (Karateng, dkk, 2002). Tools ini digunakan dengan cara melibatkan beberapa informan sebagai langkah awal memahami kondisi desa terkait pengelolaan sumberdaya hutan.

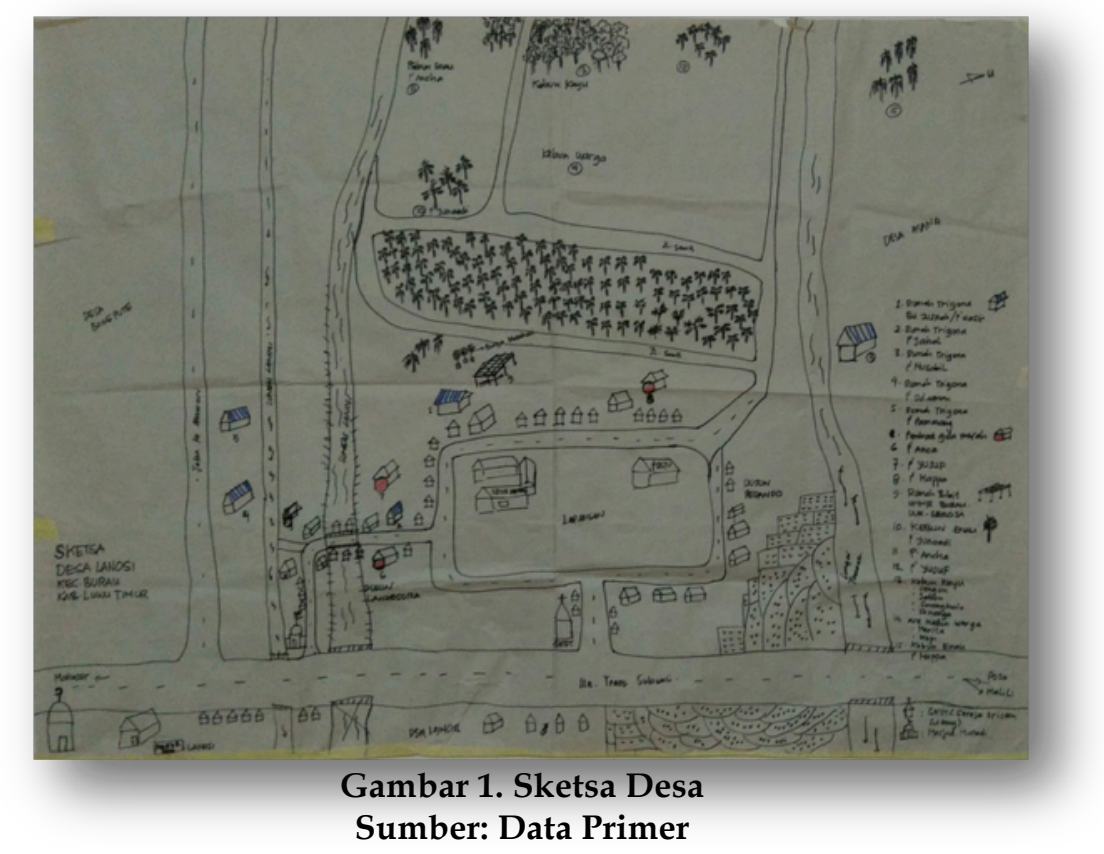


Tools PRA tersebut bertujuan mengetahui zona sumberdaya hutan baik yang telah dan sementara maupun yang belum dikelola masyarakat khususnya yang relevan dengan sistem kepercayaan masyarakat dan peran perempuan terhadap pengelolaan sumberdaya hutan. Fungsi lain adalah memperoleh informasi dimana letak rumah informan serta lokasi kegiatannya dalam mengelola sumberdaya hutan, sarana prasarana dan kelembagaan baik yang relevan dengan pengelolaan sumberdaya hutan maupun yang berfungsi sebagai sarana penunjang. Tools PRA lain yang digunakan adalah transek sumberdaya hutan, teknik observasi yang dikombinasi dengan wawancara untuk mengkonfirmasi data yang diperoleh melalui proses wawancara saat membuat sketsa desa. Pengamatan dengan menggunakan teknik ini lebih mengenal dan mengamati lebih tajam tentang kondisi penggunaan sumberdaya hutan.

Observasi Partisipasi, pengamatan berikutnya adalah mengamati kegiatan pengelolaan sumberdaya hutan di level rumah tangga yang dipilih sebagai unit analisis bagaimana berbagi peran dalam mengelola sumberdaya hutan. Kegiatan yang diobservasi adalah budidaya lebah madu trigona menjelang panen. Pengamatan dilakukan dengan cara observasi partisipasi (participatory observation). Hasilnya adalah berbagai peran yang dilakukan khususnya perempuan dan laki-laki pada level rumah tangga, sarana yang digunakan ketika melakukan budidaya madu trigona, kapan dan dimana mengelola sumberdaya hutan tersebut.

Wawancara mendalam (indepth interview), seperti yang diuraikan dalam (Karateng, A., dkk, 2002: 33-34) adalah; pertama menemui informan kunci, dimana informan menyampaikan keadaan dirinya, pandangan, atau pemikirannya tentang masyarakat dan lingkungannya khususnya terkait kepercayaan masyarakat dan peran perempuan terhadap pengelolaan sumberdaya hutan.

Dokumentasi, proses dokumentasi yang dilakukan adalah mendokumentasi obyek yang dikaji seperti keadaan umum desa, sumberdaya hutan, kegiatan pengelolaan sumberdaya hutan, proses implementasi program kegiatan pengelolaan sumberdaya hutan baik saat masih berlangsung, maupun setelah program kegiatan selesai dilaksanakan. Peran-peran perempuan dalam pengelolaan sumberdaya hutan baik dilakukan secara individu maupun secara kolektif. Mengumpulkan data sekunder seperti profil Desa Lanosi dan literatur yang relevan.

Informan utama yang dipilih adalah Perempuan sebagai Ketua Kelompok Tani Hutan Rakyat, Koordinator Desa dan Ketua Unit Usaha Kreatif. Alasan memilih ketiganya karena memiliki aktifitas pengelolaan sumberdaya hutan yang beragam serta peran yang berbeda tetapi memiliki orientasi dan tujuan 
sama. Ditambah dua orang informan laki-laki yang memahami banyak hal terkait sejarah perkembangan dan sistem kepercayaan pengelolaan sumberdaya hutan di Desa Lanosi termasuk peran perempuan. Pertama adalah sebagai salah seorang ketua kelompok budidaya lebah madu trigona di mana anggotanya sebagian perempuan. Kedua adalah seorang tokoh masyarakat Pamona yang banyak mengetahui sistem kepercayaan masyarakat Pamona sebagai penduduk asli Desa Lanosi.

\section{Hasil Penelitian dan Pembahasan}

\section{- Kepercayaan Masyarakat Terkait Pengelolaan Sumberdaya Hutan}

Kegiatan pengelolaan sumberdaya hutan di Desa Lanosi yang dilakukan oleh masyarakat sejak dulu tidak lepas dari kepercayaan masyarakat terkait pengelolaan sumberdaya hutan itu sendiri. Masyarakat Suku Pamona yang pertama mendiami desa tersebut, masih percaya bahwa hutan dihuni oleh penguasa hutan yang wujudnya gaib. Oleh sebab itu, sebelum melakukan kegiatan di dalam hutan maka perlu meminta izin kepada penguasa hutan tersebut melalui kegiatan ritual. Sebagaimana cerita Pak Rahim (47 tahun) yang menuturkan bahwa:

".....Pada saat warga ingin mengambil sesuatu di hutan atau menebang pohon khususnya masyarakat Pamona maka dilakukan ritual yang namanya "metompa" (Pamona) atau "metabe"(Bugis), metompa atau metabe artinya meminta izin kepada penguasa hutan (makhluk gaib yang ada di hutan) sebelum melakukan. Kalau orang Bugis mengatakan "mappasabbi", artinya menyampaikan maksud dan tujuan di hutan. Ritual itu dilakukan dengan cara membawa sesuatu (sesaji) kemudian dibaca dengan bacaan tertentu oleh warga yang mau melakukan aktifitas di hutan misalnya menebang pohon, mengambil nira, dan lain-lain" biasa didampingi oleh orang tua kampong. (Rahim, 47 Tahun).

Ungkapan tersebut menunjukkan bahwa jika masyarakat ingin memanfaatkan sumberdaya hutan, tidak bisa dilakukan sesuai kemauannya saja, karena ada kepercayaan yang diyakini bahwa segala sesuatu yang ada di hutan ada penjaganya, dan jika ingin memanfaatkannya maka harus minta izin terlebih dahulu kepada penguasa hutan melalui ritual yang disebut "metompa" (Pamona) atau "metabe (Bugis)". Kemudian Pak Rahim lanjut mengungkapkan ceritanya;

.....Jika ada warga melakukan aktifitas pengambilan kayu di hutan tanpa melakukan "metompa", maka bisa terjadi sesuatu bala. Pernah ada kejadian sebelumnya, warga yang meninggal di Desa Lanosi ini, terjepit kayu atau tertindis kayu, kesurupan, kemudian sakit kepala dan muntah-muntah yang warna muntahnya kekuningkuningan. Jika terjadi hal tersebut itu tandanya warga tersebut mengalami "kemboa"(Pamona) atau "amparangi"(Bugis) maksudnya keteguran oleh arwah yang sudah meninggal dimana arwahnya berada di dalam hutan tersebut. Dulu ada seorang Manteri Kesehatan yang mengalami hal tersebut, tetapi dia tidak percaya, kemudian dia 
pergi berobat ke Makassar selama sebulan, tapi penyakitnya tidak sembuh-sembuh. saat itu dia disarankan ke orang pintar di kampung untuk berobat, pada saat dia diobati sama orang pintar (dukun), yang mengobati sarankan untuk menziarahi kuburan orang tuanya. Setelah pak manteri tersebut datang menziarahi kuburan orang tuanya, sakit kepalanya pun langsung sembuh". (Rahim, 47 Tahun).

Hal ini menunjukkan bahwa jika ada warga yang melakukan pelanggaran terhadap kepercayaan yang diyakini tersebut, maka ada akibat metafisik yang terjadi atas pengaruh dari "penguasa hutan", karena melanggar tata krama ketika memasuki hutan, hal itu sudah terjadi berulang kali dibuktikan oleh masyarakat desa Lanosi sendiri, sehingga mereka sangat percaya.

Pak Nasir (50 tahun) juga menguraikan bahwa:

"...Jika ingin masuk hutan harus memberi salam terdahulu dan meminta izin jika ingin menebang pohon, yang dikenal dengan istilah "metabe" (Bugis) yakni meminta izin kepada penjaga hutan atau penguasa, tidak boleh sembarang berkata-kata karena bisa mengalami "kemboa" (Pamona) yakni sakit kepala dan muntah-muntah. Orang Bugis mengatakan "Amparangi", oleh arwah yang pindah-pindah dan diyakini bermukim di hutan tersebut. Untuk mengobati jika ada warga mengalami "kemboa" maka dilakukan "diluntuh"(pamona) oleh orang tertentu di kampung ini dengan cara rambut di ubun-ubun ditarik sambil membaca bacaan tertentu, jika bunyinya "maddetto" (Bugis), berarti memang orang tersebut benar-benar mengalami "kemboa". (Nasir, 50 Tahun).

Beberapa larangan di hutan yang harus diperhatikan lanjut Pak Nasir dan Pak Rahim bahwa;

“.... di Desa Lanosi ini ada beberapa larangan, jika larangan itu tidak diindahkan maka bisa jadi akibatnya terjadi kematian seperti berbagai pengalaman masyarakat yang sudah terjadi sebelumnya, di kampung ini kita dilarang mandi telanjang di sungai atau di tempat terbuka, mencuci belanga (uring tanah) atau kuali yang terbuat dari tanah, mencuci kelambu, bakar udang, bakar terasi, kepiting, dan lipan. Jika ada warga yang melakukan hal itu, maka dia mengalami sakit keras atau bahkan bisa jadi mengalami "kematian". (Nasir, 50 Tahun).

Sedangkan cerita Pak Rahim tentang makhluk gaib sebagai penguasa hutan mengatakan;

“...Dulu pak pernah ada kejadian di hutan dimana seorang warga ternaknya mati. Lokasi kejadian di hutan bagian barat Desa Lanosi. Awalnya warga itu menyampaikan ke warga lain kalau hilang sapinya, sehingga orang kampung ramai-ramai mencari, tetapi nanti mati baru ditemukan. Padahal lokasi ditemukannya sapi tersebut selalu dilewati oleh warga tim pencari sapi. Sapi tersebut baru muncul setelah korban yang kehilangan sapi melakukan ritual melepas ayam hitam oleh orang tua kampung, baru muncul sapi yang hilang itu. Itu pun sapinya sudah mati, bisa jadi ada sesuatu yang pernah dilakukan di hutan tersebut warga tadi tidak melakukan ritual. Sehingga sampai sekarang orang di kampong ini percaya kalau di hutan itu ada makhluk gaib sebagai penguasa hutan". (Rahim, 47 Tahun). 
Begitulah kepercayaan orang Pamona dan Bugis di Lanosi terkait bagaimana melakukan ritual sebelum melakukan aktifitas pengelolaan sumberdaya hutan dan sanksi-sanksi jika melakukan pelanggaran. Sampai sekarang kepercayaan tersebut masih diyakini oleh pada umumnya warga Desa Lanosi, karena mereka menyaksikan betapa sakitnya jika melakukan pelanggaran terhadap kepercayaan yang sudah lama hidup di masyarakat Desa Lanosi, khususnya masyarakat Suku Pamona dan Bugis.

Implikasi dari sistem kepercayaan yang masih terjaga sampai saat ini oleh masyarakat di Desa Lanosi mengakibatkan hutan masih terjaga, sehingga dengan sendirinya masyarakat secara tidak sadar melakukan konservasi terhadap kawasan hutan tersebut. Walaupun masyarakat tidak bermaksud menjaga hutan, tetapi kepercayaan tersebut bertujuan agar makhluk gaib yang diyakini sebagai penguasa hutan tidak memberi sanksi bagi warga yang melanggar norma-norma yang mereka yakini.

Masyarakat tidak lepas dari sistem pengetahuan tentang ilmu gaib yang mempengaruhi kehidupannya, sehingga kepercayaan terkait metompa dan metabe merupakan unsur yang mempengaruhi tindakan masyarakat. Penyakit yang mengidap masyarakat tidak lepas dari keyakinan mereka bahwa tersebut dipengaruhi oleh makhluk gaib, sehingga cara pengobatannyapun juga dengan cara melibatkan makhluk gaib yang diperan oleh dukun (lihat Koentjaraningrat, 1989: 374).

\section{- Norma dan Nilai dalam Pengelolaan Sumberdaya Hutan}

Untuk mengelola sumberdaya tersebut masing-masing ada aturannya, baik yang sudah ada secara turun temurun maupun dirumuskan sendiri oleh anggota kelompok khususnya kegiatan pengelolaan sumberdaya hutan yang dikelola berbasis kelompok masyarakat (Zain, A.S., 1996). Norma-norma tersebut dianut dan dipatuhi untuk mengatur berjalannya suatu aktifitas secara tertib untuk mencapai tujuannya. Dalam setiap aktifitas masyarakat pengelolaan sumberdaya hutan di Desa Lanosi terdapat norma-norma yang dianut dan masih berlaku sampai saat ini.

Adapun norma-norma yang diatur oleh masyarakat pada berbagai aktifitas yang dimaksud adalah:

1) Pembuatan Gula Merah. Kegiatan pembuatan gula merah di Desa Lanosi yang dikelola secara turun temurun sebagaimana yang dilakukan di beberapa daerah di Sulawesi Selatan, Sumber utama pembuatan gula merah adalah air nira dari pohon enau. Pohon enau tersebut setiap keluarga sudah dikapling sejak dulu secara turun turun temurun. Masyarakat umumnya sudah mengetahui status penguasaan lokasi 
rumpun pohon enau oleh setiap keluarga yang sudah dikuasakan. Setiap rumpun pohon enau tidak boleh diambil airnya kecuali keluarga yang sudah memperoleh hak pengelolaan. Sementara keluarga yang lainpun tidak berani mengambil air nirah pada pohon yang bukan dalam wilayah pengelolaannya.

2) Mengambil Kayu Bakar. Masyarakat Desa Lanosi sampai saat ini masih memanfaatkan kayu sebagai bahan untuk memasak, meskipun sudah memiliki kompor gas, tetapi umumnya masih menggunakan kayu bakar untuk memasak, seperti memasak air untuk air minum, memasak nasi dan lain-lain. Begitu pula bagi keluarga yang membuat gula merah, kayu bakar merupakan kebutuhan utama. Karena memasak air nirah membutuhkan waktu berjam-jam sampai matang dan diolah menjadi gula cetak. Oleh karena itu, jika ada warga menebang kayu, maka keluarga atau tetangga datang beramai-ramai untuk mengambil ranting yang tidak digunakan oleh pemilik kayu dijadikan sebagai bahan bakar. Kegiatan tersebut dilakukan baik oleh laki-laki maupun oleh perempuan. Saat disimpan atau ditumpuk di kebun lokasi penebangan kayu tersebut, tidak boleh satupun ada keluarga yang mengambilnya, itu berarti sudah ada keluarga sebagai pemiliknya.

3) Budidaya Lebah Madu Trigona. Budidaya lebah madu trigona adalah program yang diinisiasi oleh masyarakat sendiri setelah mendengar ada informasi jika di Kabupaten Luwu Utara ada sekelompok petani hutan sudah berhasil mengelola lebah madu Trigona. Sehingga aturan yang dibuat juga berbasis pada inisiatif masyarakat sendiri, berdasarkan informasi yang diperoleh dari sistem pengelolaan lebah madu trigona di Luwu Utara. Melalui Tim Penyuluh BP DAS Dinas kehutanan Kabupaten Luwu Timur masyarakat Desa Lanosi mendapatkan pelatihan dan pendampingan, begitu juga dari pihak Universitas Hasanuddin melalui bimbingan Almarhum Prof. Dr. Andi Mappatobasila.

Mereka membuat aturan khususnya pembagian peran antara laki-laki dan perempuan, baik pekerjaan yang hanya bisa dilakukan oleh laki-laki, maupun yang hanya bisa dilakukan oleh perempuan atau bisa dilakukan oleh keduanya. Jika pekerjaan yang menimbulkan resiko tinggi maka diserahkan kepada laki-laki seperti pengambilan induk (kroni) di hutan, pembuatan kotak budidaya dan rumah budidaya, sementara pekerjaan yang sifatnya ringan seperti pemeliharaan dan panen maka bisa dilakukan oleh perempuan atau dilakukan secara bersama.

Sementara pengelolaan rumah budidaya awalnya dibuat hanya satu sebagai percontohan di dekat kebun milik salah satu pengurus kelompok (ketua kelompok), kemudian masing-masing pengurus dan anggota 
membuat rumah budidaya di kebun atau halaman rumah masing-masing. Setiap anggota memproduksi sendiri madu Trigona dan menjualnya sendiri dengan harga yang ditentukan sendiri oleh masing-masing pemilik rumah budidaya, karena harganya bervariasi ada harga 50 ribu untuk ukuran botol YouC $140 \mathrm{ml}$ ada juga yang menjual dengan harga 60 ribu rupiah, begitu pula untuk ukuran botol sirup ABC isi $525 \mathrm{ml}$ ada yang menjual seharga 150 ribu rupiah, ada juga yang menjual seharga 250 ribu rupiah dengan alasan berbeda. Pengurus atau anggota kelompok yang menjual dengan harga 250 ribu memiliki harga yang berbeda tersebut memiliki alasan masing-masing tentang kualitas produknya.

Norma-norma yang disepakati baik formal maupun informal menunjukkan bahwa masyarakat membutuhkan aturan agar mereka dapat menjalankan kegiatannya secara kolektif agar tujuan dapat tercapai. Kekuatan norma yang lahir secara informal (tidak tertulis) yang dianut masyarakat secara turun temurun lebih ditaati ketimbang norma-norma yang disusun secara formal atau tertulis (Hijjang, P., 2005 dan Salman, D., 2016). Sementara norma-norma yang disusun secara tertulis, seperti norma-norma tentang pengelolaan UMHR/UUK yang berisi antara lain pengurus dan anggota wajib mengikuti kegiatan-kegiatan termasuk pelatihan, selain itu pengurus wajib membuat laporan pertanggungjawaban secara berkala. Tetapi saat pengurus dan anggota tidak menjalankan kewajibannya, sanksi yang disepakati juga tidak berlaku. Sehingga aturan tetap aturan tetapi tidak menjadi rujukan untuk ditaati.

Dua bentuk norma tersebut menunjukkan bahwa norma yang sifatnya lisan tetapi sanksinya berat jika dilanggar, maka semua warga patuh terhadap norma tersebut. Apalagi diyakini bahwa sanksi yang diperoleh berasal dari makhluk gaib sebagai penguasa hutan yang bisa menyebabkan sakit bahkan kematian. Berbeda halnya dengan AD/ART UMHR yang tertulis, meskipun ada aturan tetapi tetap dilanggar, sanksinya pun relatif ringan, sehingga norma tersebut tidak menjadi perhatian serius bagi pengurus dan anggota kelompok.

4) Program Berdaya Hijau. Program berdaya Hijau yang difasilitasi atas kerjasama MCAI dengan Konsorsium Berdaya Hijau mengimplementasikan program melalui pendampingan kelompok Tani Hutan Rakyat yang tergabung di dalam UMHR (Unit Manajemen Hutan Rakyat), salah satu unit dari UMHR adalah UUK (Unit Usaha Kreatif) dimana seluruh pengurus dan anggotanya adalah Perempuan. Dalam menjalankan program difasilitasi oleh seorang fasilitator masyarakat yang disebut FO (field Officer) untuk merumuskan berbagai aturan, baik aturan pengelolaan 
rumah bibit maupun pengelolaan kelompok itu sendiri. Adapun hal-hal yang diatur adalah:

- Aturan pembangunan dan pengelolaan Rumah Bibit. Sumber pendanaan pembangunan rumah bibit melalui program Berdaya Hijau sebanyak 50 juta rupiah untuk kapasitas 40 ribu bibit Sengon dan Jabon, sementara lokasi pembibitan merupakan swadaya kelompok dengan status pinjam pakai selama kegiatan pembibitan dilaksanakan oleh kelompok dalam hal ini UUK. Pembangunan rumah bibit dibuat melalui mekanisme tender sebagaimana diatur dan ditetapkan oleh Program Berdaya Hijau, namun realitasnya pelaksanaan pembangunan rumah bibit dilaksanakan sendiri oleh UMHR sebagai pemenang tender. Meskipun sudah diumumkan melalui koran lokal di Luwu Timur, tetapi kebijakan MCAI memungkinkan dilaksanakan sendiri oleh UMHR atas persetujuan pihak MCAI yang berkedudukan di Jakarta. Untuk pengadaan benih, Polybag disiapkan oleh pengurus UMHR sementara pengisian tanah ke dalam polybag, penyemaian, penyapihan, pemeliharaan dilaksanakan oleh pengurus UUK. Pemindahan bibit yang layak tanam berukuran tinggi lebih dari $30 \mathrm{~cm}$, diangkut dari rumah bibit ke rumah pengurus/anggota UMHR dikoordinir oleh Kordes (Koordinator Desa). Masing-masing Kordes mendistribusikan ke lokasi penanaman milik pengurus/anggota UMHR. Sampai saat ini masih ada bibit kayu yang belum tersalur ke lokasi milik pengurus dan anggota dengan berbagai alasan seperti tidak ada lagi lokasi yang siap ditanami atau ada anggota yang tidak bersedia lokasinya ditanami bibit tersebut karena mengganggu tanaman lainnya. Alasan lainnya karena tidak disiapkan biaya penanaman oleh pelaksana program.

- Aturan pengelolaan kelompok. UUK sebagai unit dari UMHR menjalankan perannya tidak lepas dari aturan yang dibangun oleh UMHR, sebagai unit pengelola rumah bibit membuat aturan internal dalam menjalankan perannya, adapun hal-hal yang diatur dalam UUK bersama UMHR adalah: (a) Penempatan Sekretariat UMHR/UUK ditempatkan di dekat rumah bibit dalam hal ini di rumah ketua UMHR, (b) Masing-masing pengurus (ketua, sekretaris, bendahara dan anggota) menjalankan fungsinya sesuai tugasnya masing-masing melalui prinsip-prinsip transparan, partisipatif dan akuntabilitas, (c) Seluruh keputusan diambil berdasarkan atas musyawarah, (d) Setiap pengurus/anggota kelompok yang terlibat pada kegiatan pembibitan mendapat kompensasi HOK (hari orang kerja) sebanyak 70.000 ribu rupiah setiap hari yang difasilitasi oleh Program Berdaya Hijau dikelola oleh UMHR/UUK, (e) Setiap anggota UUK yang terlibat pada kegiatan 
pembibitan diatur waktunya sehingga semua mendapat kompensasi HOK secara merata, (f) Pertemuan kelompok dilakukan secara berkala, sesuai waktu yang disepakati untuk membahas capaian hal-hal terkait peran masing-masing pengurus dan anggota kelompok, penggunaan dana kelompok serta kendala-kendala yang dihadapi.

Sementara itu nilai-nilai lokal yang masih dianut masyarakat Desa Lanosi adalah ketika ada kegiatan bersama dilaksanakan di masyarakat, mereka memaksakan diri meluangkan waktunya untuk bisa hadir, meskipun pada prinsipnya tidak setuju terhadap kegiatan yang dilaksanakan, karena mereka didelegasikan oleh pemerintah desa sebagai utusan untuk menjadi pengurus dan anggota kelompok, sehingga ketika ada kegiatan yang tidak dihadiri, mereka merasa berat tidak melaksanakan amanah yang diembannya. Rasa kebersamaan saling membantu masih hidup di Desa Lanosi, sehingga sikap ketidaksetujuan tidak diperlihatkan, yang penting mereka bisa hadir dan mengambil bagian pada setiap kegiatan di level kelompok.

\section{- Peran Perempuan dalam Pengelolaan Sumberdaya Hutan}

Peran perempuan dalam pengelolaan sumberdaya hutan tidak hanya pada ruang domestik tetapi juga pada ruang publik. Berbagai program penguatan atau pemberdayaan perempuan mendorong ke arah tersebut untuk memperkuat posisi perempuan dalam pengambilan keputusan (Bank Dunia, 2005, Pinky, C., 2010, Thamrin, J., 2010, Nugroho, R, 2008 dan Wiliam, D, Vries, 2006). Berbagai kegiatan yang dilakukan perempuan dalam pengelolaan sumberdaya hutan seperti yang dilakukan oleh beberapa keluarga antara lain;

1) Pengelolaan Gula Merah. Salah satu produk dari pengelolaan air nira dari enau adalah gula merah yang telah dikelola secara turun temurun oleh warga Desa Lanosi. Adapun peran perempuan pada setiap tahapan kegiatan pengelolaan gula merah adalah;

- Pengambilan air nira dilakukan setiap pagi oleh Laki-laki, namun sehari sebelumnya pada sore hari dilakukan pemasangan tempat penampungan air nira dengan menggunakan cerigen, yang sebelumnya menggunakan tong bambu bulat, namun yang menyiapkan seluruh peralatan tersebut adalah perempuan.

- Air nira yang sudah diambil dari pohon enau dibawa ke tempat pembuatan gula merah, lalu disaring saat dituang pada tungku pemanas, sebelumnya dicampur kulit batang pohon yang disebut "bulli" (stilah setempat) bahannya berasal dari akar pohon tertentu yang rasanya pahit, biasa juga dicampur kulit batang pohon nangka, fungsinya agar air nira tersebut bisa menjadi gula merah cetak yang berkualitas. Jika tidak menggunakan ramuan tersebut, maka gula 
merah tidak bisa berhasil, proses mencampur ramuan tersebut dilakukan secara bersama oleh laki-laki dan perempuan.

- Memasak air nira yang kemudian diolah menjadi gula cetak, pada tahap ini dilakukan oleh perempuan sampai pada tahap memasukkan bahan dasar pembuatan gula merah pada cetakan yang terbuat dari tempurung kelapa. Ukuran Satu cetakan adalah tempurung kelapa tua yang dibelah dua. Sementara tempurung yang digunakan dibuat oleh laki-laki.

- Setelah gula merah tersebut kering, maka diangkatlah dari cetakannya kemudian dibungkus dengan menggunakan daun pisang kering, lalu disiapkan untuk dipasarkan. Kegiatan ini dilakukan oleh perempuan dibantu oleh anak-anak dan anggota keluarga lainnya.

2) Budidaya Madu Lebah Trigona. Keterlibatan perempuan dalam pengelolaan sumberdaya hutan khususnya pengelolaan madu trigona dapat dilihat pada tabel 1 berikut ini;

Tabel 1. Peran Laki-Laki dan Perempuan pada Kegiatan Budidaya Lebah Madu Trigona

\begin{tabular}{|c|c|c|c|}
\hline \multirow{2}{*}{ No. } & \multirow{2}{*}{ Tahapan Kegiatan } & \multicolumn{2}{|c|}{ Pembagian Peran } \\
\hline & & Laki-Laki & Perempuan \\
\hline 1 & $\begin{array}{l}\text { Pembuatan papan untuk kotak } \\
\text { budidaya }\end{array}$ & $\begin{array}{l}\text { Pengambilan material dari } \\
\text { hutan }\end{array}$ & - \\
\hline 2 & $\begin{array}{l}\text { Pembuatan Rumah/Pondok } \\
\text { budidaya }\end{array}$ & $\begin{array}{c}\text { mendirikan } \\
\text { pondok/Rumah Budidaya }\end{array}$ & Memasak \\
\hline 3 & $\begin{array}{l}\text { Melakukan survey sarang } \\
\text { lebah madu Trigona }\end{array}$ & $\begin{array}{l}\text { Dilakukan di hutan dimana } \\
\text { lebah Trigona membuat } \\
\text { sarang }\end{array}$ & - \\
\hline 4 & $\begin{array}{l}\text { Pengambilan sarang lebah } \\
\text { madu }\end{array}$ & $\begin{array}{c}\text { Dilakukan pada pohon } \\
\text { yang sudah ditandai } \\
\text { sebelumnya setelah survey }\end{array}$ & - \\
\hline 5 & Melakukan kontrol hama & $\begin{array}{r}\text { Mengecek apakah ada sem } \\
\text { besar dilakukan oleh la } \\
\text { perempuc }\end{array}$ & $\begin{array}{l}\text { icak atau lebah } \\
\text { ki ataupun }\end{array}$ \\
\hline 6 & $\begin{array}{l}\text { Melakukan penanaman } \\
\text { tanaman sebagai sumber } \\
\text { bahan makanan lebah trigona. }\end{array}$ & $\begin{array}{l}\text { Menanam tanaman bunga } \\
\text { jambu, papaya, kopi di dek }\end{array}$ & $\begin{array}{l}\text { tahari, pisang, } \\
\text { ndok budidaya }\end{array}$ \\
\hline 7 & $\begin{array}{l}\text { Melakukan control kotak } \\
\text { budidaya } 4-6 \text { bulan }\end{array}$ & $\begin{array}{r}\text { Mengontrol apakah sudah } \\
\text { cara mengangkat kotak, jika } \\
\text { maka dinilai sia }\end{array}$ & $\begin{array}{l}\text { panen dengan } \\
\text { ah dirasa penuh } \\
\text { nen }\end{array}$ \\
\hline 8 & Panen pertama & $\begin{array}{r}\text { Plastik pada kotak dibuka } \\
\text { pada kotak dituang di b } \\
\text { membuka Kotak harus men } \\
\text { pada muka sebagai pengar } \\
\text { kerumunan lebah m }\end{array}$ & $\begin{array}{l}\text { mudian madu } \\
\text { n. Bagi yang } \\
\text { nakan kain kasa } \\
\text { dari gangguan } \\
\text { tirgona } \\
\end{array}$ \\
\hline 9 & Pemindahan ke kotak lain & $\begin{array}{r}\text { Induk dari lebah madu dip } \\
\text { ke kotak la }\end{array}$ & hkan sebagian \\
\hline 10 & $\begin{array}{l}\text { Kontrol panen berikutnya } \\
\text { setiap bulan }\end{array}$ & $\begin{array}{r}\text { Kotak dikontrol setiap bu } \\
\text { penuh atau } \mathrm{b}\end{array}$ & $\begin{array}{l}\text { apakah sudah } \\
\text { n }\end{array}$ \\
\hline 11 & Panen berikutnya & $\begin{array}{l}\text { Panen berikutnya dilakukar } \\
\text { pertama, yakni plastic pen }\end{array}$ & $\begin{array}{l}\text { erti pada panen } \\
\text { kotak dibuka }\end{array}$ \\
\hline
\end{tabular}




\begin{tabular}{|c|c|c|c|}
\hline \multirow{2}{*}{ No. } & \multirow{2}{*}{ Tahapan Kegiatan } & \multicolumn{2}{|c|}{ Pembagian Peran } \\
\hline & & Laki-Laki & Perempuan \\
\hline & & \multicolumn{2}{|c|}{$\begin{array}{l}\text { kemudian madu dituang pada baskon. Yang } \\
\text { menuang harus menggunakan alat pengaman } \\
\text { (kain kasa) }\end{array}$} \\
\hline 12 & $\begin{array}{l}\text { Penyediaan wadah dan } \\
\text { peralatan sebelum panen } \\
\text { (botol dan saringan dan kain } \\
\text { kasa) }\end{array}$ & \multicolumn{2}{|c|}{$\begin{array}{l}\text { Penyediaan baskon, botol syrup } \mathrm{ABC} \text { dan UC } \\
\text { sebagai botol yang digunakan untuk pemasaran } \\
\text { madu, baskon, tapisan dan kain kasa }\end{array}$} \\
\hline 12 & $\begin{array}{l}\text { Pemindahan madu dari kotak } \\
\text { budidaya ke botol madu }\end{array}$ & - & $\begin{array}{c}\text { Menuang madu } \\
\text { dari baskom } \\
\text { dengan } \\
\text { menggunakan } \\
\text { tapisan serta } \\
\text { memisahkan } \\
\text { sarangnya dan } \\
\text { propolis dimana } \\
\text { masih terdapat } \\
\text { madu. }\end{array}$ \\
\hline 13 & $\begin{array}{l}\text { Pemindahan sarang ke kotak } \\
\text { baru }\end{array}$ & \multicolumn{2}{|c|}{$\begin{array}{l}\text { Sarang yang sudah diambil madunya } \\
\text { dipindahkan ke kotak lain. }\end{array}$} \\
\hline 13 & Pemasaran madu & - & $\begin{array}{l}\text { Memasarkan } \\
\text { madu }\end{array}$ \\
\hline
\end{tabular}

Sumber: Data Primer 2018

Kegiatan budidaya lebah madu trigona dilakukan oleh laki-laki dan perempuan berdasarkan atas saling pengertian, dalam setiap tahapan lakilaki memahami perannya begitu pula perempuan (suami, istri dan anggota rumah tangga lainnya). Jika tahapan itu dirasakan berat dilakukan oleh salah satu pihak, maka yang lain memahaminya. Seperti saat melakukan survei sarang, karena jaraknya tidak menentu, maka suami yang mengambil peran dan melarang istrinya atau perempuan anggota rumah tangga yang lain untuk ikut serta. Tetapi jika ada yang bisa dilakukan oleh perempuan saja tanpa keterlibatan laki-laki atau kedua-keduanya bisa dilakukan bersama maka mereka melakukan secara sukarela. Tidak ada aturan khusus yang dibuat sebagaimana saat mengontrol hama, dan pada saat panen.

3) Pembibitan Sengon dan Jabon. Kegiatan pembibitan bibit kayu Sengon dan Sengon dilakukan sejak program KBR (kebun Bibit Rakyat) Dinas Kehutanan Kabupaten Luwu Timur pada tahun 2013 kemudian dilanjutkan oleh Program Berdaya Hijau tahun 2016-2018. Dalam melakukan pembibitan ada beberapa tahapan yang dilalui, pada setiap tahapan kegiatan peran perempuan juga sangat signifikan. Adapun pembagian peran laki-laki pada setiap tahapan pembibitan adalah: 
ETNOSIA: Jurnal Etnografi Indonesia 4(1): Sistem Kepercayaan dan Peran Perempuan

Tabel 2. Pembagian Peran Laki-Laki dan Perempuan Pada Kegiatan Pembibitan

\begin{tabular}{|c|c|c|c|}
\hline \multirow{2}{*}{ NO } & \multirow{2}{*}{ Tahapan Kegiatan } & \multicolumn{2}{|c|}{ Peran } \\
\hline & & Laki-Laki & Perempuan \\
\hline 1 & Pemilihan Benih & $\begin{array}{c}\text { Pemilihan Benih dibeli } \\
\text { di balai Kehutanan } \\
\text { Makassar }\end{array}$ & - \\
\hline 2 & Perendaman & - & $\begin{array}{c}\text { Dilakukan oleh ketua } \\
\text { UMHR (perempuan), } \\
\text { karena telah } \\
\text { berpengalaman } \\
\text { sebelumnya pada } \\
\text { program KBR. Dengan } \\
\text { cara direndam air hangat } \\
\text { kemudian dimasukkan ke } \\
\text { dalam karung Goni }\end{array}$ \\
\hline 3 & Penyemaian & $\begin{array}{l}\text { Dilakukan bersama laki } \\
\text { istri). Setelah bibit tumb } \\
\text { tunas yang keluar di se } \\
\text { disiapkan wadah buat } \\
\text { cara dibuka pada subul } \\
\text { di }\end{array}$ & $\begin{array}{l}\text { aki dan perempuan (suami } \\
\text { h, dengan tanda sudah ada } \\
\text {-sela lubang karung, maka } \\
\text { ibit untuk disemai dengan } \\
\text { hari, kemudian siap untuk } \\
\text { apih. }\end{array}$ \\
\hline 4 & $\begin{array}{l}\text { Pengadaan tanah dan } \\
\text { kompos }\end{array}$ & $\begin{array}{l}\text { Dilakukan oleh laki- } \\
\text { laki pengurus/anggota } \\
\text { UMHR, yang sebagian } \\
\text { besar istrinya juga } \\
\text { pengurus UUK. }\end{array}$ & - \\
\hline 5 & Pembelian Polybag & $\begin{array}{c}\text { Dilakukan oleh } \\
\text { pengurus UMHR di } \\
\text { Makassar (laki-laki) }\end{array}$ & - \\
\hline 6 & $\begin{array}{l}\text { Pengisian tanah ke } \\
\text { dalam polybag }\end{array}$ & - & $\begin{array}{c}\text { Dilakukan oleh pengurus } \\
\text { dan anggota UUK baik } \\
\text { yang ada di Desa Lanosi } \\
\text { maupun desa lainnya. }\end{array}$ \\
\hline 7 & $\begin{array}{l}\text { Pengaturan blok pada } \\
\text { rumah bibit }\end{array}$ & $\begin{array}{r}\text { Dilakukan bersama ole } \\
\text { untuk memudahkar } \\
\text { pem }\end{array}$ & $\begin{array}{l}\text { laki-laki dan perempuan, } \\
\text { proses penyapihan dan } \\
\text { iharaan }\end{array}$ \\
\hline 8 & Penyapihan & - & $\begin{array}{l}\text { Dilakukan pengurus/ } \\
\text { anggota UUK }\end{array}$ \\
\hline 9 & Pemeliharaan & - & $\begin{array}{l}\text { Dilakukan oleh anggota } \\
\text { UUK dengan cara } \\
\text { mencabut rumput yang } \\
\text { mulai tumbuh di polybag, } \\
\text { atau ada yang mati } \\
\text { sehingga disapih ulang }\end{array}$ \\
\hline 10 & $\begin{array}{l}\text { Pembuatan papan } \\
\text { informasi bibit }\end{array}$ & $\begin{array}{l}\text { Dibuat oleh laki-laki } \\
\text { dengan tujuan untuk } \\
\text { mengetahui jumlah } \\
\text { polybag pada setiap } \\
\text { blok, tanggal }\end{array}$ & - \\
\hline
\end{tabular}




\begin{tabular}{|c|c|c|}
\hline \multirow{2}{*}{ NO } & \multirow{2}{*}{ Tahapan Kegiatan } & Peran \\
\hline & & Perempuan \\
\hline & & $\begin{array}{c}\text { penyapihan sehingga } \\
\text { umur bibit bisa } \\
\text { diketahui }\end{array}$ \\
\hline 10 & $\begin{array}{l}\text { Pemindahan bibit dari } \\
\text { rumah bibit ke desa } \\
\text { lokasi penanaman milik } \\
\text { anggota UMHR. }\end{array}$ & $\begin{array}{c}\text { Dilakukan secara bersama baik laki-laki maupun } \\
\text { perempuan, laki-laki yang mengangkat dari rumah } \\
\text { bibit ke kendaraan, sementara perempuan yang } \\
\text { menghitung jumlah bibit yang diangkut serta } \\
\text { mencatat jumlah bibit yang didistribusi ke masing- } \\
\text { masing desa yang dikoordinir oleh masing-masing } \\
\text { Kordes (Koordinator Desa) }\end{array}$ \\
\hline
\end{tabular}

Sumber: Data Primer 2018

Pada kegiatan pembibitan Sengon dan Jabon, peran perempuan sangat signifikan pada setiap tahapan kegiatan. Menurut penyuluh kehutanan Kabupaten Luwu Timur sebagai narasumber saat memberi materi ketika pelaksanaan kegiatan pelatihan pembibitan di Desa Lanosi, bahwa ada tahapan dimana perlakukan bibit membutuhkan kelembutan dan kesabaran. Khususnya pada saat penyemaian dan penyapihan, pada tahap itu membutuhkan peran perempuan berdasarkan pengalaman sebelumnya. Karena pertumbuhan bibit kayu tersebut sangat sensitif, jika dilakukan secara terburu-buru dan tidak telaten maka hasilnya tidak optimal.

\section{Kesimpulan}

Sistem kepercayaan masyarakat yang masih dianut melalui metompa dan metabe merupakan upaya secara tidak sadar masyarakat Desa Lanosi mencegah penebangan hutan secara massif khususnya untuk alih fungsi lahan menjadi perkebunan lada (merica), sehingga sampai saat ini hutan di Lanosi masih terjaga. Meskipun masih terdapat warga yang membuka lahan untuk kebun merica tetapi jumlahnya relatif sedikit.

Sementara itu model proses pembagian peran laki-laki dan perempuan dalam pengelolaan sumberdaya hutan merupakan proses "konstruksi peran gender", dimana antara laki-laki dan perampuan selama prosess menerapkan budidaya lebah madu trigona masing-masing saling memahami satu dengan yang lain, mereka dari awal tidak diarahkan siapa yang melakukan apa oleh penyuluh kehutanan, tetapi mereka secara alami berproses dan pada akhirnya mereka saling memahami dimana mereka berperan sendiri-sendiri, dan dimana mereka berperan bersama, bahkan dimana mereka bisa saling bertukar peran, proses itu berlangsung secara alamiah pada program lebah madu Trigona.

Berbeda halnya dengan peran perempuan pada kegiatan pembibitan kayu Sengon dan Jabon, dari awal dirumuskan kegiatan apa yang dikerjakan oleh 
perempuan, kegiatan apa yang dikerjakan oleh laki-laki dan kegiatan yang dilakukan secara bersama-sama. Meskipun demikian pada proses berjalan, ada peran yang sesungguhnya bisa dikerjakan bersama baik laki-laki maupun perempuan tetapi pada akhirnya diminta perempuan yang melaksanakan, yakni kegiatan penyapihan. Ada juga kegiatan yang dirumuskan hanya lakilaki yang berperan, namun akhirnya perempuan yang melakukan yakni mengangkut material tanah untuk mengisi polibag. Karena disadari bahwa kegiatan tersebut bisa juga dikerjakan oleh perempuan.

Pembagian peran tersebut memberi indikasi keduanya saling berperan setara dalam pengelolaan sumberdaya hutan, untuk meningkatkan pendapatan rumah tangganya sekaligus melestarikan sumberdaya hutan secara berkelanjutan (Agusnawati, 2005 dan Widodo, S., 2009). Peran tersebut lahir dari kesadaran masing-masing untuk secara bersama-sama mengelola sumberdaya hutan semata-mata untuk pemenuhan kebutuhan rumah tangganya. Hanya saja ada perbedaan mencolok etos antara masyarakat Bugis dan Pamona, dimana masyarakat Bugis lebih produktif dari Masyarakat Pamona, ditandai dengan rumahnya lebih besar serta kebunnya lebih luas dan hasilnya juga lebih banyak. Berbeda masyarakat Pamona, yang penting kebutuhan rumah tangga sudah tertutupi dalam waktu singkat, mereka sudah bersyukur.

\section{Daftar Pustaka}

Bank Dunia, (2005). "Pembangunan yang Berperspektif Gender", Dian Rakyat: Jakarta.

Chandra, E., (2010). “Politik Keiburumahtanggaan Perempuan", Antropologi Indonesia.31 (3): 200-211

Faqih, M., (2008). “ Analisis Gender dan Transformasi Sosial”, Insist Press: Yogyakarta.

Febrianto, A., (2016). “ Antropologi Ekologi”, Kencana: Jakarta

Hijjang, P., (2005). "Pasang dan Kepemimpinan Ammatoa: Memahami Kembali Sistem Kepemimpinan Tradisional Masyarakat Adat dalam Pengelolaan Sumberdaya Hutan di Kajang Sulawesi Selatan", Antropologi Indonesia. 29 (3): $225-268$

Koentjaraningrat., (1989). "Pengantar Ilmu Antropologi”. Aksara Baru: Jakarta. (2014). "Sejarah Teori Antropologi I". UI Press: Jakarta. 
Kabar.news.Com, 13/05/2017. “Longsor di Luwu Timur, 7 Orang Meninggal,", diunggah Tanggal 11/10/2017

Karateng, A.; Bunna, B. Syafiuddin; Bachtiar, B.; Halim, P.; Yunus, Y.; Lanta, J.; Amir, M., (2002). " Participatory Local Social Development Versi NGO", Modul Pelatihan JICA PMD-LML: Makassar.

Laksono, P.M.; A.S. Sumijati: Gandarsih, T,: Pakpahan M,; Rianty A,; Hendrijani A.B., (2000). "Perempuan di Hutan Mangrove" Galang Press: Yogyakarta

Nugroho, R, (2008). “Gender dan Strategi Pengarus Utamaannya di Indonesia" Pustaka Pelajar: Yogyakarta.

Pinky, C., (2010). "Dibalik Panggung Reforma Agraria: Perjuangan Tersembunyi Perempuan Tani", Antropologi Indonesia. Vol. 31(3):185-199

Salman, D., (2016)." Sosiologi Desa", Ininnawa: Makassar

Sulawesi Community Foundation (SCF), (2015). “Laporan Penelitian Peningkatan Pendapatan Rumah Tangga Melalui Perbaikan Tata Kelola Hutan Rakyat Berkelanjutan Yang Berkontribusi Pada Penyerapan Gas Rumah Kaca di Kabupaten Luwu Timur": Makassar.

Thamrin, J., (2010). “ Membuka Ruang Publik: Gerakan Demokratisasi Lokal Melalui Forum Warga dan Peran Strategis Perempuan", Antropologi Indonesia. Vol. 31(3):216-218

Wiliam, D, Vries, (2006). “Gender Bukan Tabu" Center for International Forestry Research (CIFOR): Bogor, Indonesia

Widodo, S., (2009)." Analisis Gender Dalam Kegiatan Pengelolaan Hutan Rakyat dan Kontribusi Hutan Rakyat Terhadap Pendapatan Rumah Tangga" Embrio. Vol.6 (2): 148-153.

Zain, A.S., (1996)." Hukum Lingkungan Konservasi Hutan", Rineka Cipta: Jakarta, Indonesia. 